\title{
IS THE GREAT DECOUPLING REAL?
}

\author{
Marinko ŠKARE ${ }^{1}$, Damian ŠKARE $^{2}$ \\ ${ }^{1}$ Juraj Dobrila University of Pula, Economics and Tourism "Dr. Mijo Mirkovic", \\ Preradoviceva 1, Preradoviceva 1, Pula, 52100 Croatia \\ ${ }^{2}$ School of Economics Pula, Kovačićeva ul. 3, 52100, Pula, Croatia \\ E-mails: ${ }^{1}$ mskare@unipu.hr (correspondingauthor); ${ }^{2}$ damian.skare@skole.hr
}

Received 04 February 2017; accepted 24 April 2017

\begin{abstract}
The great decoupling is real. Productivity and employment/wages link changed after 1980 in many countries, not just the U.S. This study investigates the productivity and employment/wages link (1950-2014) looking for empirical proof of the "great decoupling" put forward by Brynjolfsson and Mcafee (2013). The results should stimulate policymakers to openly question why real wages and productivity don't line up with the theory. We use the Hodrick and Prescott (1997) filter to isolate trends in real wages, labor share in GDP, and labor productivity and rolling correlation to explore if the great decoupling is real. We have found that the great decoupling i.e. the divergence between real wages/employment and productivity is present in all countries (10 in the sample). The dynamics of the great decoupling are however different between the countries although year 1980 seems to be a dominant breaking point for the start of the phenomena. This paper provides multicounty empirical proof of the presence of the great decoupling phenomena and explores its dynamics over 1950-2014. Policy makers as well as firms and unions should take the existence of this phenomena seriously since it can have significant consequences on economic growth and labor markets' functioning.
\end{abstract}

Keywords: the great decoupling, wage-productivity gap, employment, OECD countries, Hodrick-Prescott filter, rolling correlation.

JEL Classification: C13, E24, E25, O40.

\section{Introduction}

Earlier studies on the link between productivity and real wages/employment vary in nature and conclusion. Productivity is regarded as the engine of economic growth attracting researchers to explore the linkage between productivity and real wages resulting in the standard productivity/wage economic theory. The theory states that labor markets are always looking for the equilibrium between real wages and productivity. Productivity above real wages drive wages up (since firms demand more labor) and in the time of low capacity utilization and low productivity (with real wages resistance), demand for labor is expected to fall driving real wages down. Many factors such as low unionization rates, shadow economy, and shadow labor markets can account for 
the observed divergence between productivity and real wages. Methodological issues such as wages deflation procedures, real wages indicators (cash and health, pension benefits versus cash only compensations), labor productivity indicators and share of labor and capital in the economy affect the observed dynamics between labor productivity and real wages/employment. Real wages and productivity dynamics show increasing divergence since 1980 (ILO 2012) with labor productivity growing faster than real wages and employment. The great decoupling refers to registered productivity - wages/ employment gap resulting from technology advancement (Brynjolfsson, Mcafee 2013), rising inequality (Bivens, Mishel 2015) and falling labor share in GDP (Baker 2007). Considered importance of the question, there is an abundance of literature on the great decoupling phenomena (mainly reports and blogs) but are lagging published articles in journals. Empirical studies on the great divergence focus on individual country (case) studies or panel data analysis over a limited time span while this study investigates data on ten countries over 1950-2014. Perhaps the structural change toward an information economy from a manufacturing economy could also explain some of the decoupling. This may be the same as the analysis by Brynjolfsson and Mcafee (2013) although theirs may focus on the use of technology by labor rather than the structural change away from manufacturing.

The non-linear relationship between the wage-productivity gap and unemployment explored by López-Villavicencio and Silva (2011) is dependent on the employment protection legislation framework in OECD countries. Meager and Speckesser (2011) reviewed the empirical relation between wages, productivity and employment on international data in different time periods and the unit of observation for EU and OECD countries. Their data show countries (like the U.S. or UK) with wages better aligned with productivity exhibits better future employment performances in relation to Germany keeping wages below productivity growth. Elgin and Kuzubas (2013) performed a cross-country panel study on the data set for 31 countries over 1960-2009 examining the determinants (unemployment rate, capital deepening, unionization and price level) of the wage-productivity gap. The level of workforce unionization and unemployment according to this study are primary drivers behind the registered wage-productivity gap. Wage productivity dynamics show a different relationship in former socialist economies as in the study of Nikulin (2015). Wage-productivity divergence is present in Estonia, Hungary, Slovakia, Czech Republic and Slovenia while the strong positive association between wages and productivity is evident in Poland. Pessoa and van Reenen (2013) found no evidence on the net decoupling on data for the UK. Brynjolfsson and Mcafee (2013) put forward the idea that technological advancement destroys jobs resulting in the divergence (great decoupling) between constant growth in labor productivity and real wages/employment lagging growth. Among the body of literature on the great decoupling, their work attracted more attention since the link between technological progress and labor productivity growth is the more obvious and empirically evidenced.

Previous studies mainly focus on the wage-productivity gap and determinants behind on an individual country level (single country) or use panel data over one limited time and dimension span. This study focuses on the research of the real wages (labor compensation), employment and real labor productivity over the considerable time span and ten 
different economies. Considering the importance of methodological issues as well as national economies' structural differences or heterogeneity among firms and workers, this paper will try to resolve these open issues and provide empirical evidence on the presence/absence of the great decoupling on an international level.

The purpose of this research is to answer the question: is the great decoupling real (statistically significant) in a sense that it demands further research or is it just a temporary deviation in the wage-productivity gap dynamics? Thus, the paper's key research points are:

- To determine if the divergence between observed healthy labor productivity growth and lagging real wages/employment is statistically valid (not a measurement error or statistical bias).

- To explore how the great divergence (if present) on an international level has changed over the last sixty years and identify the turning points in the association between labor productivity growth and real wage/employment.

Research results generated from this study should provide researchers with a greater understanding of the great divergence and stimulate further (more advanced) studies in the field. Information generated from this paper can significantly assist policy makers in the application of the wage moderation policy.

After the introduction on the great decoupling phenomena in the review section, the most significant works on the topic are examined. The data and methodology section provides details on the data and methodology used in the study to analyze the relationship between labor productivity and real wage/employment in ten different economies over sixty years. Findings are discussed and summarized in the last section, a concluding section discussing the theoretical and practical implication of the study and prospective for further research.

\section{Literature review}

The wage productivity link is the essential part of the efficiency wage theory and economics in general. Traditional economic theory regards the association between productivity and wages as positive, converging or oscillating around unit elasticity. Technological advancement boosts productivity, which according to the efficiency wage theory lead to a wage increase. Increasing labor marginal productivity (resulting from new technology implementation in the firms) pushes the demand for labor and in the end, causes an increase in the general wage level. Since wages are on average household's main source of income, rising wages stimulate average household purchasing power and consumption, leading to future economic growth (Patra, Nayak 2012). Whenever productivity is above the wage level, firms engage in labor demand pushing wages upward and productivity downward. The wage level rising above the efficiency wage, i.e. wages growing more rapidly in relation to productivity slows down the labor demand, putting downward pressure on wages. The dynamics between wages-productivity-employment decides on the faith of the firms because firms in the industries with wages rising above productivity level cannot keep up with the actual output and employment level. The only path to break this vicious cycle is to invest in technological improvement followed by an increase in the gross fixed capital investments and the reigniting of productivity. 
Table 1 presents the summary of results for the previous study on the productivity and wage/employment link.

Table 1. Overview on productivity-wage-employment link studies

\begin{tabular}{|c|c|c|}
\hline Author(s) & Study description & Results \\
\hline Harris and Todaro (1970) & $\begin{array}{l}\text { Impact of migration on } \\
\text { productivity and wages }\end{array}$ & $\begin{array}{l}\text { Rural-urban wage gap is } \\
\text { maintained by labor market } \\
\text { frictions }\end{array}$ \\
\hline Mincer (1974) & $\begin{array}{l}\text { Wage premium over marginal } \\
\text { productivity depends on workers' } \\
\text { characteristics }\end{array}$ & $\begin{array}{l}\text { Human capital causes marginal } \\
\text { wage rise }\end{array}$ \\
\hline $\begin{array}{l}\text { Shapiro and Stiglitz } \\
\text { (1984) }\end{array}$ & Efficiency wage policy & $\begin{array}{l}\text { Unemployment and efficiency } \\
\text { wages induce workers' productivity }\end{array}$ \\
\hline $\begin{array}{l}\text { Krueger } \\
\text { and Summers (1988) }\end{array}$ & $\begin{array}{l}\text { High-wage industries and wage } \\
\text { differentials }\end{array}$ & $\begin{array}{l}\text { Sectors with high industry profits } \\
\text { pressure wage level upward }\end{array}$ \\
\hline $\begin{array}{l}\text { Abowd, Kramarz, and } \\
\text { Margolis (1999) }\end{array}$ & $\begin{array}{l}\text { Impact of workers' individual } \\
\text { characteristics on wages }\end{array}$ & $\begin{array}{l}\text { More productive workers earn } \\
\text { higher wages }\end{array}$ \\
\hline Spence (2002) & $\begin{array}{l}\text { Wage differentials and } \\
\text { asymmetric information }\end{array}$ & $\begin{array}{l}\text { Asymmetric information influence } \\
\text { productivity and wages }\end{array}$ \\
\hline $\begin{array}{l}\text { Heckman, Lochner, and } \\
\text { Todd (2006) }\end{array}$ & $\begin{array}{l}\text { Returns on education depends on } \\
\text { the level of uncertainty }\end{array}$ & $\begin{array}{l}\text { Human capital-wage link depends } \\
\text { on associated uncertainty }\end{array}$ \\
\hline Helpman (2006) & $\begin{array}{l}\text { Trade, FDI and production } \\
\text { location influence wage rate and } \\
\text { productivity }\end{array}$ & $\begin{array}{l}\text { Global trade and firms' location } \\
\text { determine country efficiency wage } \\
\text { level }\end{array}$ \\
\hline Oreopoulos (2007) & $\begin{array}{l}\text { The link between investments in } \\
\text { education and marginal wage }\end{array}$ & $\begin{array}{l}\text { Productivity gain is now always } \\
\text { following investments in education }\end{array}$ \\
\hline $\begin{array}{l}\text { Staiger, Spetz, } \\
\text { and Phibbs }(2010)\end{array}$ & $\begin{array}{l}\text { Monopsony power and wage } \\
\text { differentials }\end{array}$ & $\begin{array}{l}\text { Labor costs are higher under } \\
\text { Monopsonistic labor market }\end{array}$ \\
\hline $\begin{array}{l}\text { Konings and } \\
\text { Vanormelingen (2010) }\end{array}$ & $\begin{array}{l}\text { Association between productivity } \\
\text { and wage differentials }\end{array}$ & $\begin{array}{l}\text { Productivity differentials drive } \\
\text { wage differentials }\end{array}$ \\
\hline Manning (2011) & $\begin{array}{l}\text { Bargaining mechanism and wage } \\
\text { level }\end{array}$ & $\begin{array}{l}\text { Bargaining mechanism control } \\
\text { wage and productivity divergences }\end{array}$ \\
\hline van Biesebroeck (2011) & $\begin{array}{l}\text { Bargaining power impact on } \\
\text { wage level }\end{array}$ & $\begin{array}{l}\text { Bargaining power can maintain } \\
\text { wage above productivity levels }\end{array}$ \\
\hline Fox and Smeets (2011) & $\begin{array}{l}\text { Human capital impact on } \\
\text { productivity level }\end{array}$ & $\begin{array}{l}\text { Human capital has low impact on } \\
\text { productivity differences }\end{array}$ \\
\hline $\begin{array}{l}\text { Oreopoulos, von Wachter, } \\
\text { Heisz (2012) }\end{array}$ & $\begin{array}{l}\text { Demand for labor and } \\
\text { unemployment affect equilibrium } \\
\text { wages }\end{array}$ & $\begin{array}{l}\text { Equilibrium wage is not always } \\
\text { associated with productivity alone }\end{array}$ \\
\hline Brummund (2012) & $\begin{array}{l}\text { Firms' market power impact on } \\
\text { wage level }\end{array}$ & $\begin{array}{l}\text { Firms' with high market power } \\
\text { have limited control on the labor } \\
\text { market and wages }\end{array}$ \\
\hline $\begin{array}{l}\text { Brynjolfsson and Mcafee } \\
(2013)\end{array}$ & The great decoupling theory & $\begin{array}{l}\text { The divergences between } \\
\text { productivity, wages and } \\
\text { employment are due to } \\
\text { technological advancement }\end{array}$ \\
\hline Elgin and Kuzubas (2013) & $\begin{array}{l}\text { Wage-productivity gap } \\
\text { interaction with unemployment } \\
\text { and unionization rate }\end{array}$ & $\begin{array}{l}\text { Wage-productivity gap is higher in } \\
\text { time of unemployment and lower } \\
\text { on unionized markets }\end{array}$ \\
\hline
\end{tabular}

Source: authors' review. 
Previous studies generally research the link between the productivity growth and real wages while this paper is concerned upon empirical evidence of the divergence between labor productivity, wages and employment.

\section{Data and methodology}

Data in this study consist of macroeconomic data on real labor productivity, employment, and the share of labor compensation in GDP for ten countries ${ }^{1}$ over $1950-2014$. Being aware of the possible bias when studying the association between real wages/employment and labor productivity, this study uses appropriate data to overcome possible statistical bias (robust analysis). The list of variables used in the analysis is as follows ${ }^{2}$ :

- (RHC) Real hourly compensation, CPI deflated, index $2002=100$ (compensation includes employer expenditures for legally required insurance programs and contractual and private benefit plans, in addition to all payments made in cash or in kind directly to employees, total manufacturing - see The Conference Board definition - The Conference Board 2016b).

- (HLC) Hourly labor costs in manufacturing, index $2002=100$, (see The Conference Board definition - The Conference Board 2016b).

- (LPP) Labor productivity per hour (labor productivity per hour worked in 2015 US\$ (converted to 2015 price level with updated 2011 PPPs, index $2002=100$, see The Conference Board 2016a - Total Economy Database definition).

- (LABSH) Share of labor compensation in GDP at current national prices (index $2002=100$, see Penn World Table 9.0 definition (Feenstra et al. 2015).

- (EMP) All employed persons $2002=100$, total manufacturing (index $2002=100$, see The Conference Board definition - The Conference Board 2016b).

- (OPE) Output per person employed, $2002=100$, total manufacturing (index $2002=$ 100, see The Conference Board definition - The Conference Board 2016b).

- $(\mathrm{OPH})$ Output per hours, $2002=100$, total manufacturing (index $2002=100$, see The Conference Board definition - The Conference Board 2016b).

- (EMP1) All employed person, 2002 = 100, total economy (see The Conference Board 2016a - Total Economy Database definition).

Data sources for data collection: The Conference Board Databases - Total Economy Database and International Labor Comparison program 2016, U.S. Bureau of Labor Statistics (2013), Penn World Table 9.0.

For the sake of robustness, we use two measures of labor productivity, both the labor productivity per hour (from The Conference Board - Total Economy Database) and the output per person (from The Conference Board Database - International Labor Comparison program, 2016). Empirical results obtained in the analysis do not show impor-

\footnotetext{
${ }^{1}$ Canada, Denmark, France, Germany, Italy, Japan, Netherlands, Norway, UK.

${ }^{2}$ When studying real wages/employment and labor productivity dynamics possible bias can arise by using data on real wages deflated by using the CPI deflator, labor share change in output, cash wages instead of total labor cost compensation (social, health, pension benefits) and heterogeneity between firms and workers.
} 
tant differences when applying one or the other, proving the robustness of calculations in this paper. In this same manner, we use both data on all employed persons in total manufacturing as well as employed persons in an economy, and real hour compensation CPI deflated and the U.S. \$ basis. Because of the space constraints, accounting for only divergent results resulting from using different real wages, productivity and employment indicators will be discussed here. Empirical results insensitive to differences in the indicators used in calculation will not be discussed since no important differences in the calculation results arise when using various indicators in the applied analysis. Prior to analysis, stationarity tests checked the stationarity in the series using a battery of unit-root tests:

1. The Augmented Dickey-Fuller (ADF) test (Dickey, Fuller 1979).

2. Dickey-Fuller test (DFGLS) with GLS detrending (Elliott et al. 1996).

3. The Phillips-Perron (PP) test (Phillips, Perron 1988).

4. The Kwiatkowski, Phillips, Schmidt and Shin (KPSS) test (Kwiatkowski et al. 1992).

5. Elliot, Rothenberg, and Stock (ERS) test (Elliott et al. 1996).

6. $\mathrm{Ng}$ and Perron (NP) test (Ng, Perron 2001).

The summary of the results of applied battery of unit root tests are visible in Table 2 (individual unit root tests with test values are not presented here due to space constraint but are available on request).

To monitor the progress of the association between labor productivity and real wages/ employment we proceed as follows. First, using the HP filter (Hodrick, Prescott 1997), we extract the permanent (trend) and temporary (cycle) components from the series. We extract trend components for each individual series and individual country. The same trend component we later use to extract rolling correlations for labor productivity and

Table 2. Summary results of the battery unit root test

\begin{tabular}{|c|c|c|c|c|c|c|}
\hline Variables & $\mathrm{ADF}$ & DFGLS & PP & KPSS & ERS & NP \\
\hline RHC I(1) & Non-stationary & Non-stationary & Non-stationary & Non-stationary & Non-stationary & Non-stationary \\
\hline $\mathrm{HC} \mathrm{I}(2)$ & Non-stationary & Non-stationary & Non-stationary & Non-stationary & Non-stationary & Non-stationary \\
\hline HLC I(2) & Non-stationary & Non-stationary & Non-stationary & Non-stationary & Non-stationary & Non-stationary \\
\hline LPP I(1) & Non-stationary & Non-stationary & Non-stationary & Non-stationary & Non-stationary & Non-stationary \\
\hline LABSH I(1) & Non-stationary & Non-stationary & Non-stationary & Non-stationary & Non-stationary & Non-stationary \\
\hline EMP I(1) & Non-stationary & Non-stationary & Non-stationary & Non-stationary & Non-stationary & Non-stationary \\
\hline OPP I(1) & Non-stationary & Non-stationary & Non-stationary & Non-stationary & Non-stationary & Non-stationary \\
\hline OPH I(1) & Non-stationary & Non-stationary & Non-stationary & Non-stationary & Non-stationary & Non-stationary \\
\hline EMP1 I(1) & Non-stationary & Non-stationary & Non-stationary & Non-stationary & Non-stationary & Non-stationary \\
\hline
\end{tabular}

Notes: I(1), I(2) shows the order of integration of the series.

Source: authors' calculation using data from The Conference Board Databases - Total Economy Database and International Labor Comparison program 2016, U.S. Bureau of Labor Statistics, Penn World Table 9.0. 
real wages/employment to monitor changes in their relationship over time and to test the reality of the great divergence hypothesis. Using this approach, we were not only able to test the great divergence hypothesis over a long data period for each individual country but also monitor breaks in the series' association (rolling correlation) to identify possible causes for the change. This approach has many advantages over other possible approaches (regression, cointegration) since we explore the association between long term movements (trends) both in labor productivity and real wages/employment over time.

\section{Results}

Due to space constraint, only the results for the U.S., Japan, Germany, Italy and UK will be explored using figures, although results for other countries in the sample will be discussed. Figure 1 shows dynamics between output per hour in manufacturing (OPH index $2002=100$ ), hourly labor costs in manufacturing (HLC, index $2002=100$ ) and employed persons in manufacturing (EMP1, index $2002=100)$. The same notation for the series, variables is in use throughout the text.

Figure $1 \mathrm{a}$ and $1 \mathrm{~b}$ show that the great decoupling between labor productivity (output per hour), wages (hourly labor costs) and employment (employed persons) is real in the U.S. and Japan. Since 1950 to 1980 in the U.S. employment and wage dynamics moved in synchrony. After 1980 employment started to fall steeply after 1990 while wages remained slightly above productivity. From year 2000 employment registered a steep decline as wages tried to catch up with labor productivity entering the great decoupling phase.

Similar trends dominate in Japan during 1950-2014. The difference is in the dynamics of real wages remaining above (more than in the U.S.) labor productivity during 1975-1995. After the year 2000, real wages virtually froze and employment fell steadily with labor productivity reaching historical levels.

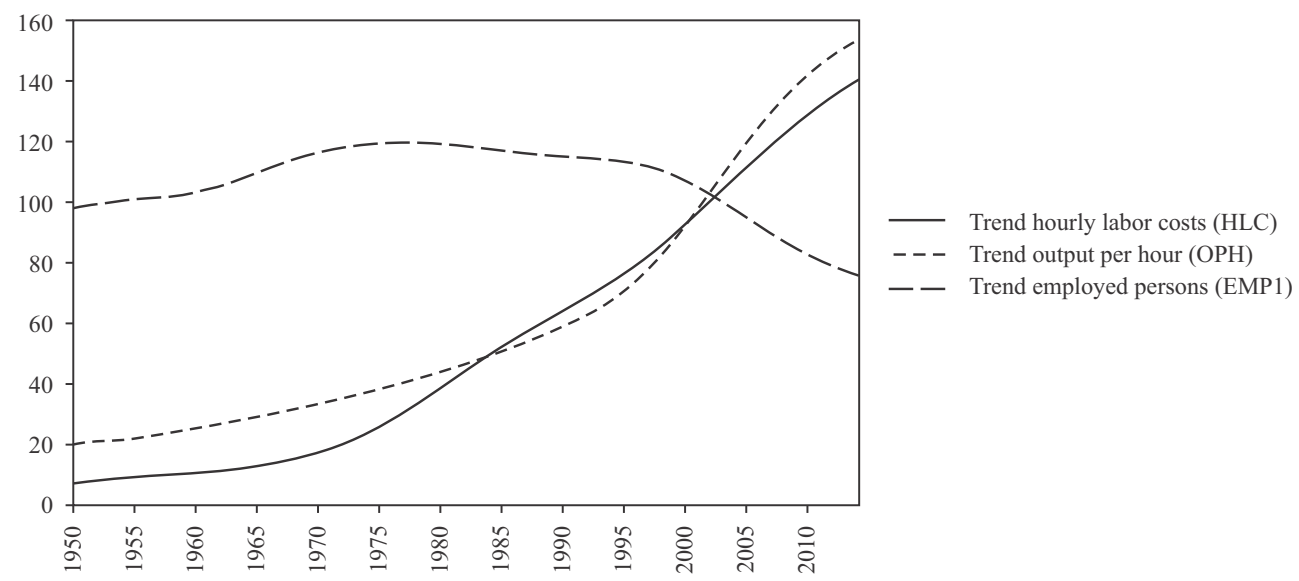

Fig.1a. The great decoupling in the U.S. 1950-2014 


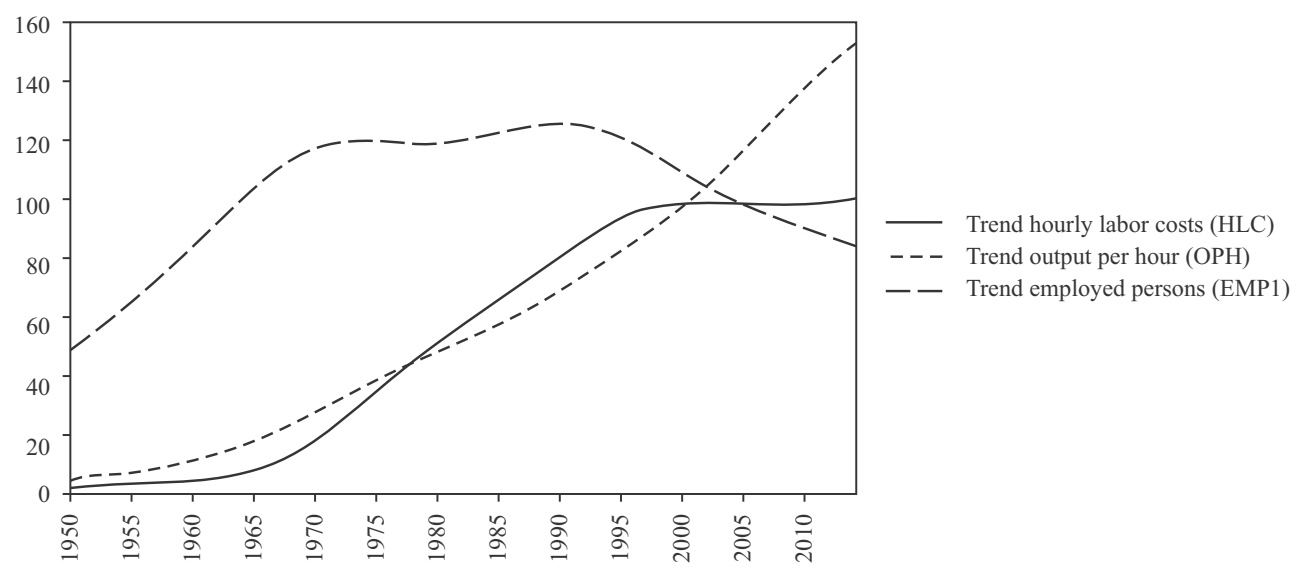

Fig.1b. The great decoupling in Japan 1950-2014

Source: authors' calculation from The Conference Board Databases - Total Economy Database and International Labor Comparison program 2016, U.S. Bureau of Labor Statistics, Penn World Table 9.0.

Figure 2 shows the great divergence over 1950-2014 for Germany and UK. In these two European economies, the trend of the great decoupling differs from the trends in the U.S. and Japan. In Germany labor productivity and wages share the same rising trend. It is only after 1995 that a barely visible decoupling started to appear. The employment trend in manufacturing in Germany steadily declined since 1970. From Figure 2 it is apparent that employment was strongly lagging productivity growth. The rising trend that both labor productivity and employment shared from 1950-1970 turned negative for employment. A similar trend but even more profound is visible for the UK economy with evident divergence between labor productivity and employment.

Labor compensation and labor productivity shared a positive association (correlation) with labor productivity rising faster than wages during 1950-2000. After the year 2000 labor productivity continues to rise reaching historical levels. In the same time, real wage also rose, exceeding the productivity growth. No decoupling between labor productivity and real wages was visible in the UK during 1950-2014. However, the same does not hold for employment. Since 1970 a strong decoupling between labor productivity and employment exists with employment under a constant sharp fall. The hypothesis of the great decoupling between labor productivity and employment thus held for the UK over 1950-2014. Table 3 displays the results for other countries in the analysis, summarizing countries that fall/do not fall under the great decoupling hypothesis.

First thing to notice from Table 3 is that the great decoupling hypothesis between labor productivity and real wages/employment holds for the U.S. and Japan. When it comes to EU countries, the hypothesis holds for labor productivity and employment but does not hold between productivity and wages. In Japan and the U.S. both real wages and employment started to lag labor productivity after the year 2000. The same did not happen in the EU because wages followed the growth of the labor productivity but employment 


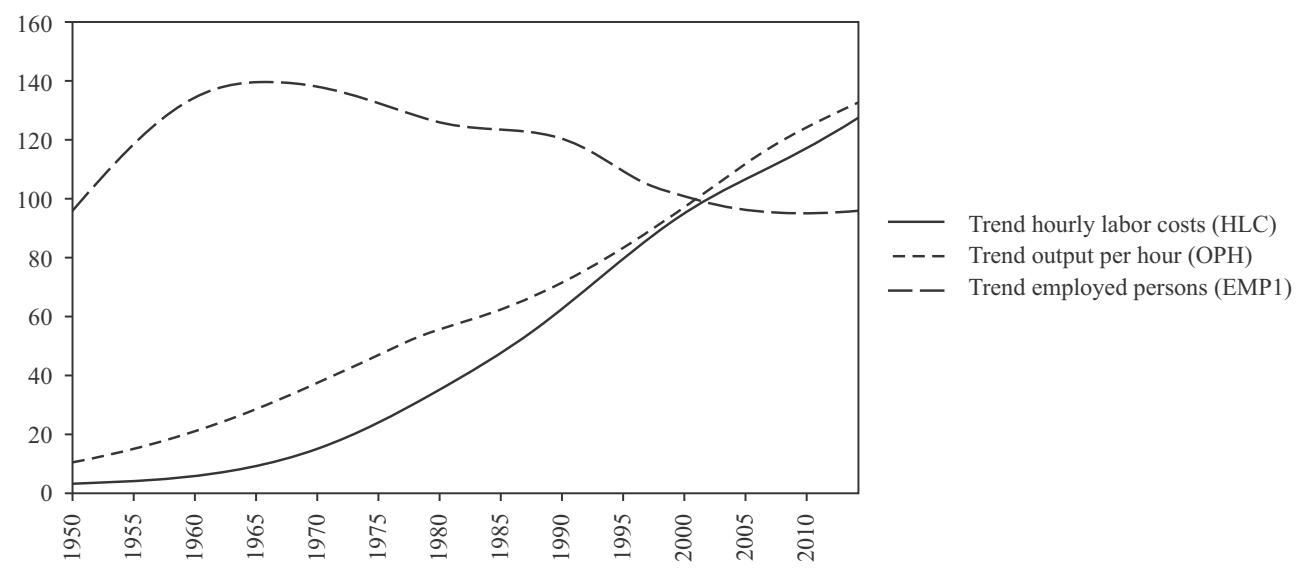

Fig. 2a. The great decoupling in Germany 1950-2014

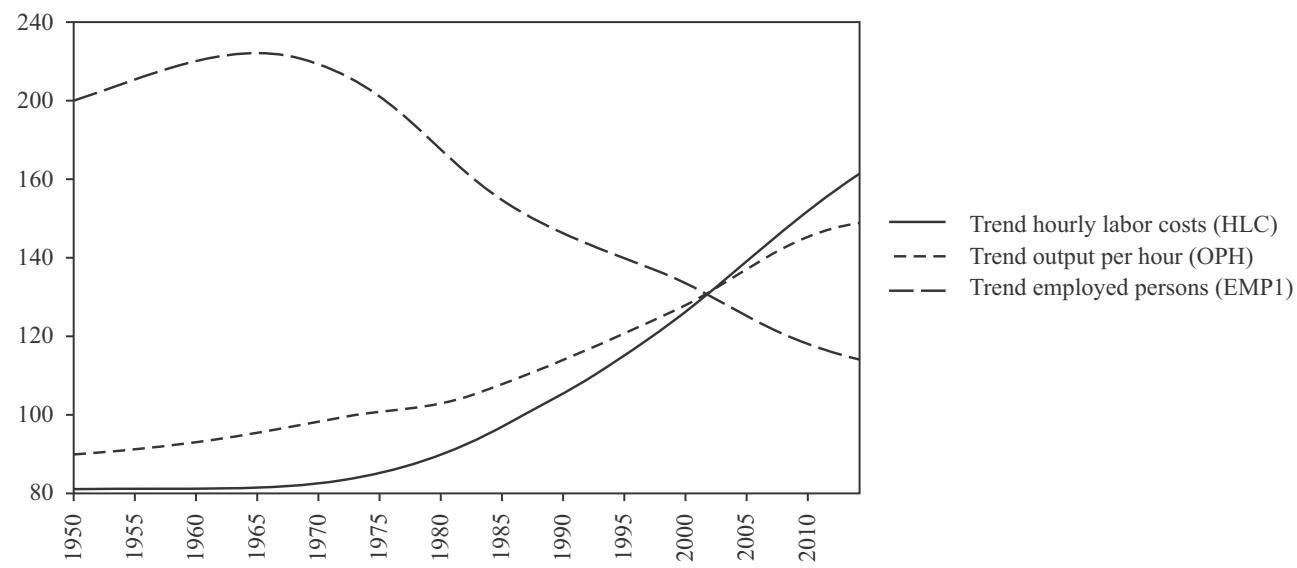

Fig. 2b. The great decoupling in UK 1950-2014

Source: authors' calculation from The Conference Board Databases - Total Economy Database and International Labor Comparison program 2016, U.S. Bureau of Labor Statistics, Penn World Table 9.0.

did not. This brings us to an interesting question, i.e. if real wages followed the growth of labor productivity in EU countries, why has "jobless growth" appeared? Standard economic theory implies whenever real wages rise personal consumption rises, leading to higher job demand. Here the data show that the first part of the theory still holds rise in real wages results in personal consumption growth but why has the demand for jobs started to fall when aggregate demand and supply rose?

To investigate the dynamics of the association between trends of labor productivity, real wages and employment a rolling (annual) correlation coefficient is calculated for each country. We can see the results of the rolling window correlation analysis on the following figures. 
Table 3. Summary of results for the great decoupling hypothesis over 1950-2014 data

\begin{tabular}{lcc}
\hline \multicolumn{1}{c}{ Country } & $\begin{array}{c}\text { Great decoupling between labor } \\
\text { productivity and real wages }\end{array}$ & $\begin{array}{c}\text { Great decoupling between labor } \\
\text { productivity and employment }\end{array}$ \\
\hline Canada & Non-existent & Exists \\
\hline Denmark & Non-existent & Exists \\
\hline France & Non-existent & Exists \\
\hline Germany & Non-existent & Exists \\
\hline Italy & Non-existent & Exists \\
\hline Japan & Exists & Exists \\
\hline Netherlands & Non-existent & Exists \\
\hline Norway & Non-existent & Exists \\
\hline UK & Non-existent & Exists \\
\hline U.S. & Exists & Exists \\
\hline
\end{tabular}

Source: authors' calculation using data from The Conference Board Databases - Total Economy Database and International Labor Comparison program 2016, U.S. Bureau of Labor Statistics, Penn World Table 9.0.

From Figure 3 it is evident that associations between labor productivity and real wages are typically positive (except for Norway) but vary in strength. For example, negative rolling correlation only exists in Norway after the year 2008 (financial crisis). High volatility in the correlation coefficient exists in the Netherlands while the highest drop in the correlation coefficients is in Japan (after 2005), Italy (2005), Germany (1995), France (2000), Canada (1980), Denmark (2000), U.S. (2005), UK (2010), Netherlands (1995). Although countries share a different pattern of association between labor productivity and real wages, several series of breakpoints appear - years 2000 and 2005. First signs of decoupling developed in the U.S. (1980), Canada (1980), Denmark (1980), France (1980), Netherlands (1970). Since examining the sources of the great decoupling is not a focus of this study, source of breaks in the correlation coefficients are not inspected. However, it seems reasonable to assume that the first signs of the great decoupling between labor productivity and real wages first showed in 1980 due to oil shocks, in 2000 - dot com companies busted and 2005 at the doorstep of the financial crisis. We can conclude that, except for Norway after 2008, the great decoupling between labor productivity and real wages is not real in our sample. Positive association between labor productivity and real wages remains in the large number of countries in our sample. However, to be precise, except for Norway, Italy and Japan also have a large drop in the rolling correlation coefficients is visible that can be in a way considered as a warning sign for the great decoupling in these two countries.

Figure 4 shows the dynamics of the great decoupling between labor productivity and employment. 
U.S.

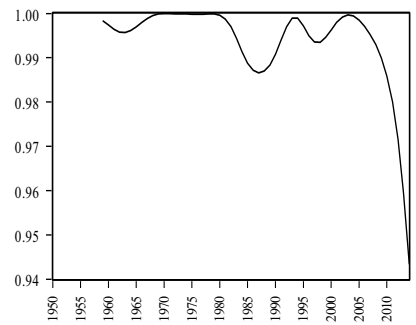

FRANCE

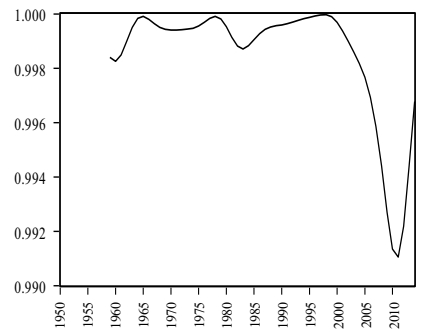

JAPAN

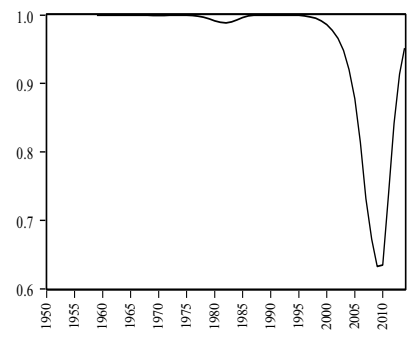

CANADA

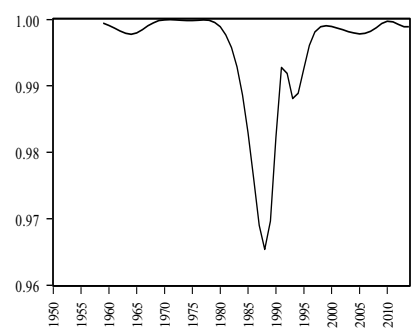

GERMANY

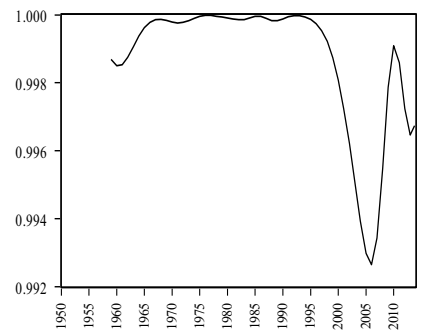

NETHERLANDS

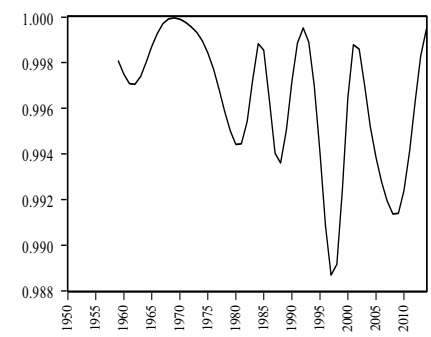

DENMARK

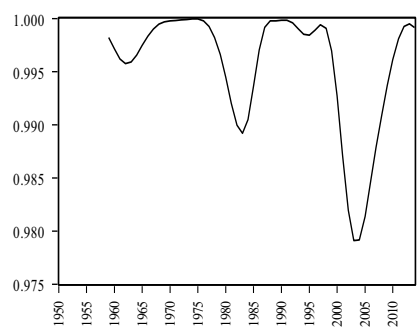

ITALY

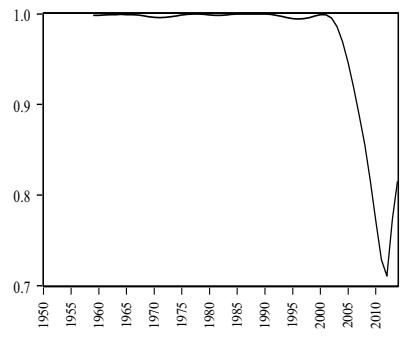

NORWAY

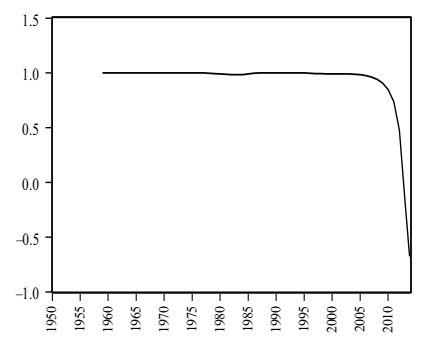

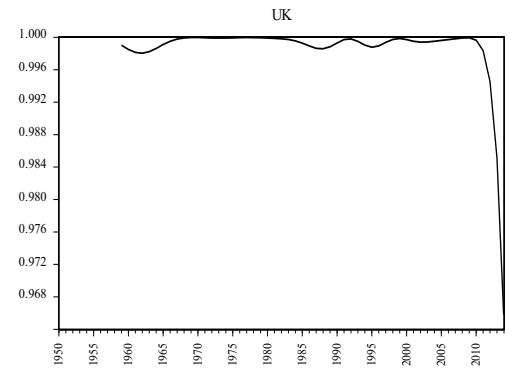

Fig. 3. Rolling correlation analysis between labor productivity and real wages 1950-2014 Source: authors' calculation using data from The Conference Board Databases - Total Economy Database and International Labor Comparison program 2016, U.S. Bureau of Labor Statistics, Penn World Table 9.0. 
U.S.

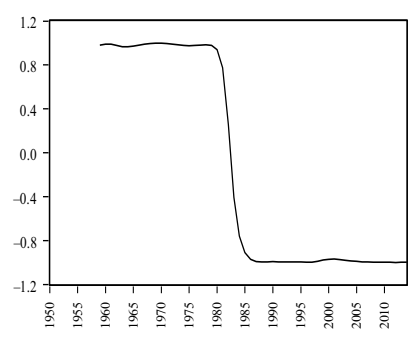

FRANCE

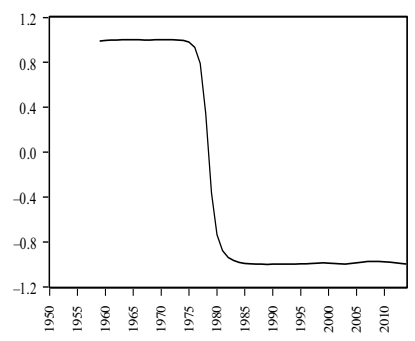

JAPAN

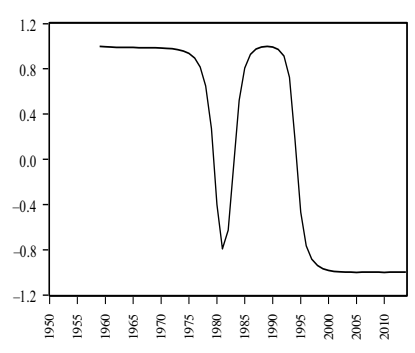

CANADA

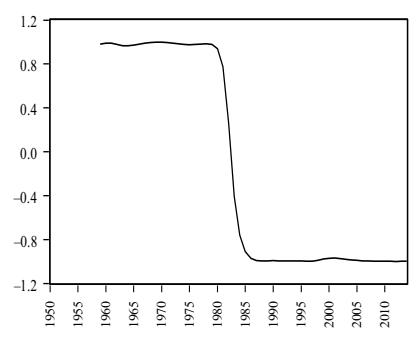

GERMANY

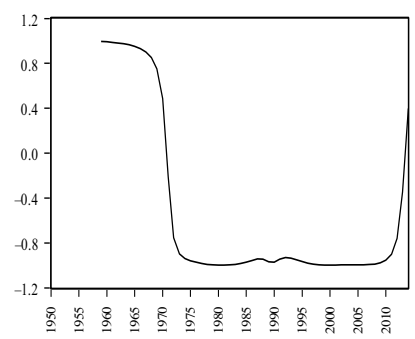

NETHERLANDS

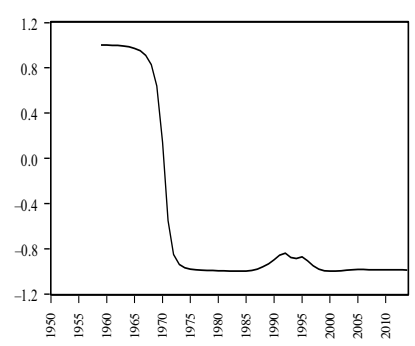

DENMARK

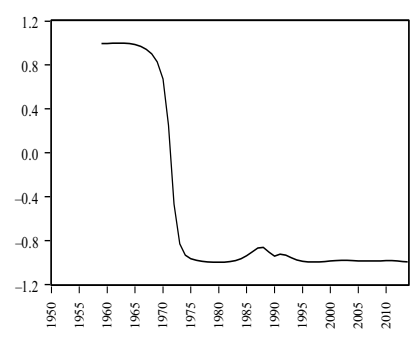

ITALY

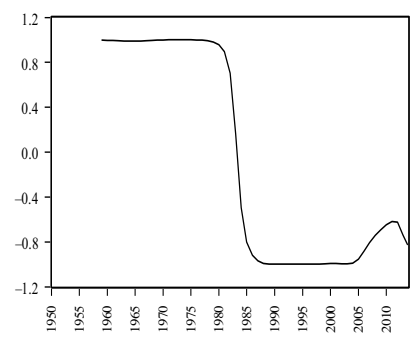

NORWAY

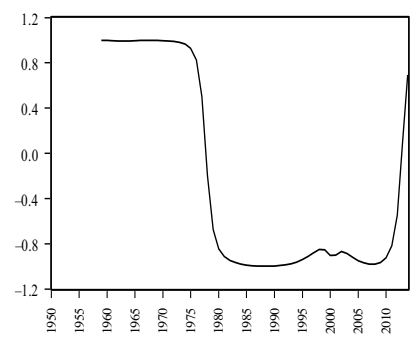

UK

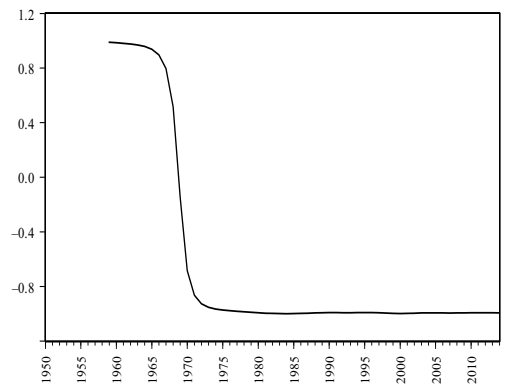

Fig. 4. Rolling correlation analysis between labor productivity and employment 1950-2014

Source: authors' calculation using data from The Conference Board Databases - Total Economy Database and International Labor Comparison program 2016, U.S. Bureau of Labor Statistics, Penn World Table 9.0. 
For most of the countries in our sample the great decoupling between labor productivity and employment is real. The period between 1970-1980 is the breaking point with positive correlation between real labor productivity and employment turning negative (the great decoupling). The U.S., Canada, Italy all exhibit a similar pattern with the great decoupling appearing after 1980 with a correlation change from +0.99 to -0.85 to 0.99 between real labor productivity and employment. The correlation coefficient turned from positive to negative for Denmark, France, Germany, the Netherlands and UK as well, only in their case, the breaking point was around 1970. In both cases, the registered great decoupling between the real labor productivity and employment remains constant up to 2014. Only Japan and Norway deviate from this pattern after a short episode of the great decoupling in Japan in 1980 the phenomena disappeared to reappear (and stay) in 1995. In the case of Norway, the great decoupling first appeared in 1978 persisting up to year 2012 and then disappeared again (correlation between real labor productivity and employment turning positive again).

As in the case of the great decoupling between real labor productivity and real wages it seems that the great decoupling between the real labor productivity and employment is somehow connected to the first and second oil shocks during the 70's and 80's. The impact of the oil shocks on the great decoupling phenomena is not the same for all countries in the sample but points to the same conclusion. The great decoupling is real, particularly in the case of employment with labor productivity registering historically high but resulting in slowing or even falling employment. Empirical evidence offered in this study points in that direction and surely demand future research on the great decoupling phenomena.

\section{Conclusions}

This study investigates the presence of the great decoupling, i.e. the divergence between real labor productivity and real wages/employment in ten countries over 1950-2014, providing empirical evidence for the phenomena. The main research objective of the study was to prove or disprove the existence of the great decoupling thesis using international data available. In addition to providing empirical evidence on the phenomena, we also observe the phenomena dynamics over more than 60 years using rolling correlation methods. Previous studies investigated the link between productivity and wages/employment using original (level) data. Our study uses a different approach by extracting the long-term component (trend) from the real labor productivity and real wages/employment to investigate the long run association (correlation). In this manner, we could observe the permanent component of the productivity/wage/employment series minimizing possible bias that could result from the statistical noise present in the series.

The great decoupling hypothesis is real and demands future research. We have found strong evidence of the great decoupling by observing the correlation of permanent components (trends) between productivity and wages/employment. To be exact, real wages are slowing down while labor productivity continues to increase with employment slowing down further. The nature of the great decoupling is different between countries. 
Patterns in the U.S., Japan and Canada show different pattern from the great decoupling dynamics in EU countries. Within EU members, a significant difference in pattern exists. The great decoupling between the real labor productivity and real wages is more prominent in Italy and Norway. Countries under the great decoupling phenomena experienced the appearance of the occurrence around the year 1980. When we observe the association between real labor productivity and employment the pattern is even more obvious. The great decoupling between productivity and employment is present in every country of the sample. In relation to the great decoupling between productivity and wages, the correlation coefficient is negative proving the divergence between productivity and employment. The divergence in the association between productivity and employment first appears around 1970 and 1980 possibly implying the impact of the oil shocks on the shift in the association. This was the case for almost any countries in the sample. It seems that the divergence between labor productivity and employment is caused by the oil shocks while the divergence between labor productivity and wages is driven by technological shocks. This is particularly true for the dot com bust (around the year 2000) and the rising share of services in GDP (impact of the internet and fourth industrial revolution).

This study shows that even under a small real wage lagging labour productivity, the standard economic theory is in trouble. According to the theory, growth in productivity should be followed by growth in wages shaping the demand for labour. When wages rise above productivity firms hire less labour and with wages below productive the demand for labour increases. As this study shows, real labour productivity raised significantly over 1950-2014 with real wages following this growth (more or less equally) with the slowest growth in Italy, Norway and Japan. At the same time, according to the theory, employment should follow the same pattern matching the equilibrium wage. Conversely, as the data here shows employment did not follow the same path resulting in the great decoupling between productivity and employment. Preliminary research here also shows that the possible cause behind the great decoupling is not inequality but indeed technological advancement. Household consumption growth in most countries in the sample follows labor productivity growth but in the same time employment is falling.

Our study indicates that a relationship between real labor productivity and real wages/ employment is changing (wages slowing down and employment falling) resulting in the great decoupling. In countries like Japan, Italy and Norway the phenomena is distinct while in other countries like France, Germany, U.S., the Netherlands, Canada, Denmark and UK is up surging. Wage policies (particularly wage moderations) set by policy makers should consider clear evidence of surging of the great decoupling phenomena. Efficiency wage theory is having difficulty dealing with this phenomenon alone so active participation by policy makers is necessary. This study provides strong empirical support for the existence of the great decoupling not just in the U.S. as usually being more discussed in an academic field but also other countries with economic structures not even close to that of the U.S. The great decoupling phenomena is going global as empirical evidence in this study suggests. 
The confidence in our empirical analysis could be strengthened by extending the number of countries in the sample and by adopting more advanced econometrical techniques. However, empirical evidence in this study remains sound and should inspire researchers and policy makers not to discharge the phenomena of the great decoupling and instead investigate it fully.

\section{References}

Abowd, J. M.; Kramarz, F.; Margolis, D. N. 1999. High wage workers and high wage firms, Econometrica 67(2): 251-333. https://doi.org/10.1111/1468-0262.00020

Baker, D. 2007. The productivity to paycheck gap: what the data show. CEPR reports and issue briefs No. 2007-11. Center for Economic and Policy Research (CEPR).

Bivens, J.; Mishel, L. 2015. Understanding the historic divergence between productivity and a typical worker's pay: why it matters and why it's real. Washington DC: Economic Policy Institute.

Brummund, P. 2012. Variation in monopsonistic behavior across establishments: evidence from the Indonesian labor market. Mimeo: Cornell University.

Brynjolfsson, E.; McAfee, A. 2013. The great decoupling, New Perspectives Quarterly 30(1): 61-63. https://doi.org/10.1111/npqu.11362

Dickey, D. A.; Fuller, W. A. 1979. Distribution of the estimators for autoregressive time series with a unit root, Journal of the American Statistical Association 74(366a): 427-431.

https://doi.org/10.1080/01621459.1979.10482531

Elgin, C.; Kuzubas, T. U. 2013. Wage-productivity gap in OECD economies, Economics 7(21): 1-21. https://doi.org/10.5018/economics-ejournal.ja.2013-21

Elliott, G.; Rothenberg, T. J.; Stock, J. H. 1996. Efficient tests for an autoregressive unit root, Econometrica 64(4): 813-836. https://doi.org/10.2307/2171846

Feenstra, R. C.; Inklaar, R.; Timmer, M.P. 2015, The Next Generation of the Penn World Table [online], [cited 16 August 2016], American Economic Review 105(10): 3150-3182. Available from Internet: www.ggdc.net/pwt

Fox, J. T.; Smeets, V. 2011. Does input quality drive measured differences in firm productivity?, International Economic Review 52(4): 961-989. https://doi.org/10.1111/j.1468-2354.2011.00656.x

Harris, J. R.; Michael, P. T. 1970. Migration, unemployment and development: a two-sector analysis, American Economic Review 60(1): 126-142.

Heckman, J. J.; Lochner, L. J.; Todd, P. E. 2006. Earnings functions, rates of return and treatment effects: the mincer equation and beyond, in E. A. Hanushek, F. Welch (Eds.). Handbook of the Economics of Education. Volume 1. Elsevier. https://doi.org/10.1016/s1574-0692(06)01007-5 Helpman, E. 2006. Trade, FDI, and the organization, Journal of Economic Literature 44(3): 589-630. https://doi.org/10.1257/jel.44.3.589

Hodrick, R. J.; Prescott, E. C. 1997. Postwar US business cycles: an empirical investigation, Journal of Money, Credit, and Banking 29(1): 1-16. https://doi.org/10.2307/2953682

ILO 2012. Global wage report 2012/13. Wages and equitable growth [online], [cited 16 August 2016]. A report. Available from Internet: http://www.ilo.org/global/research/global-reports/globalwage-report/2012/WCMS_194843/lang--de/index.htm

Konings, J.; Vanormelingen, S. 2010. The impact of training on productivity and wages: firm level evidence. IZA Discussion Paper No. 4731.

Krueger, A. B.; Summers, L. H. 1988. Efficiency wages and the Inter-industry wage structure, Econometrica 56(2): 259-293. https://doi.org/10.2307/1911072 
Kwiatkowski, D.; Phillips, P. C. B.; Schmidt, P.; Shin, Y. 1992. Testing the null hypothesis of stationarity against the alternative of a unit root, Journal of Econometrics 54(1-3): 159-178. https://doi.org/10.1016/0304-4076(92)90104-Y

López-Villavicencio, A.; Silva, J. I. 2011. Employment protection and the non-linear relationship between the wage-productivity gap and unemployment, Scottish Journal of Political Economy 58(2): 200-220. https://doi.org/10.1111/j.1467-9485.2011.00543.x

Manning, A. 2011. Imperfect competition in the labor market, Chapter 11 in D. Card, O. Ashenfelter (Eds.). Handbook of labor economics. Vol. 4, Part B, Elsevier, 973-1041.

https://doi.org/10.1016/S0169-7218(11)02409-9

Meager, N.; Speckesser, S. 2011. Wages, productivity and employment: a review of theory and international data. EEO Thematic Report, European Employment Observatory, 73.

Mincer, J. 1974. Schooling, experience, and earnings. New York: Colombia University.

Nikulin, D. 2015. Relationship between wages, labour productivity and unemployment rate in new EU member countries, Journal of International Studies 8(1): 31-40.

https://doi.org/10.14254/2071-8330.2015/8-1/3

Ng, S.; Perron, P. 2001. Lag length selection and the construction of unit root tests with good size and power, Econometrica 69(6): 1519-1554. https://doi.org/10.1111/1468-0262.00256

Oreopoulos, P. 2007. Do dropouts drop out too soon? Wealth, health, and happiness from compulsory schooling, Journal of Public Economics 91(11-12): 2213-2229.

Oreopoulos, P.; von Wachter, T.; Heisz, A. 2012. The short-and long-term career effects of graduating in a recession, American Economic Journal: Applied Economics 4(1): 1-29.

Patra, S. P.; Nayak, S. R. 2012. A theoretical study on the relationship between wages and labor productivity in industries, International Journal of Economics and Research 1(3): 157-163.

Pessoa, J. P.; van Reenen, J. 2013. Decoupling of wage growth and productivity growth? Myth and reality. CEP Discussion Paper. Centre for Economic Performance, LSE.

Phillips, P. C. B.; Perron, P. 1988. Testing for a unit root in time series regression, Biometrika 75(2): 335-346. https://doi.org/10.1093/biomet/75.2.335

Shapiro, C.; Stiglitz, J. E. 1984. Equilibrium unemployment as a worker discipline device, American Economic Review 74(3): 433-444.

Spence, M. 2002. Signaling in retrospect and the informational structure of markets, American Economic Review 92(3): 434-459. https://doi.org/10.1257/00028280260136200

Staiger, D. O.; Spetz, J.; Phibbs, C. S. 2010. Is there Monopsony in the labor market? Evidence from a natural experiment, Journal of Labor Economics 28(2): 211-236.

https://doi.org/10.1086/652734

The Conference Board. 2016a. The Conference Board Total Economy Database, November 2016 [online], [cited 16 August 2016]. Available from Internet: http:/www.conference-board.org/data/ economydatabase/

The Conference Board. 2016b. The Conference Board International Labor Comparison program [online], [cited 16 August 2016]. Available from Internet: https://www.conference-board.org/ilcprogram/index.cfm?id=18777

U.S. Bureau of Labor Statistics. 2013. International Labor Comparisons, August 2013, [online], [cited 16 August 2016]. Available from Internet: https://www.bls.gov/fls/\#compensation, accessed 16.08.2016.

Van Biesebroeck, J. 2011. Wages equal productivity. Fact or fiction? Evidence for Sub-Saharan Africa, World Development 39(8): 1333-1346. https://doi.org/10.1016/j.worlddev.2010.12.002 
Marinko ŠKARE, PhD, is Professor of Economics, Economic Research Journal Editor-in-Chief, Member of Editorial Board of several international journals, Department Economics and Tourism "Dr. Mijo Mirković" in Pula, Juraj Dobrila University of Pula. He served as Assistant Dean for Education, Faculty of Economics \&Tourism, Pula, Assistant Dean for International Cooperation, Faculty of Economics \& Tourism, Pula, Main and Team Researcher on several scientific projects, Former Dean of the Faculty of Economics \& Tourism, Pula and Former Vice President for International Cooperation, Juraj Dobrila University of Pula. He has published several books and many scientific papers about economic growth, welfare economics and poverty, human capital, economics in transition, economic philosophy and monetary economics.

Damian ŠKARE, School of Economics, Pula. His area of interests includes crypto currencies, international trade, additive manufacturing and the Great Depression of 1929. He is actively involved in several research studies within his area of interest. 